\title{
Fair Trade Governance and Diversification: The Experience of the National Smallholder Farmers' Association of Malawi
}

\section{Introduction}

Discussion surrounding the optimal arrangements for coordinating interactions between domestic and international trade is extensive. Much of the mainstream political economy literature has focused on the debate between liberalisation and state intervention (Moudud and Botchway, 2007; Smith, 2008). However, the emergence of formalised, non-state systems of governance has brought with it a burgeoning academic interest. In the most part, such private governance is intended to compensate for the perceived marginalisation of interests not sufficiently protected under the majority of existing arrangements (usually described as the 'conventional' status quo). For example, governance has focused on environmental issues (For example see: Clark and Kozar, 2011) or improving the socioeconomic fortunes of certain communities (For examples see: Barrientos and Dolan, 2006). This is particularly true where these are identified to have had limited opportunities to develop beneficial economic participation- and this paper specifically focuses on efforts to support Malawian smallholder farmers as a prime example of a community whose economic well-being has been undermined throughout its history.

One of the most significant private governance approaches to such situations has been constructed around the concept of 'fair trade', which, broadly speaking, aims to improve returns derived by Southern producers supplying certain (often commodity agricultural) goods into Northern markets (Nicholls and Opal, 2005, p. 6). This is not 
to say that fair trade activity is homogeneous however, and there are numerous sets of associated practices (Author, in press; Low and Davenport, 2006). The most prominent of these are administered by Fairtrade International and Fair Trade USA ${ }^{1}$, where independent certification is provided for a range of commodity goods produced and traded in accordance with stated requirements - usually, although not always, including the setting of minimum prices, the provision of credit and the additional payment of a Social Premia to producer groups (Doherty et al., 2012, p. 4). Other fair trade activates do not carry external certification, but have similar operational practices - for example, the payment of 'fair prices' negotiated through transparent dialogue and the provision of direct capacity building or funding for producer development - and are legitimized by reference to wider social reputations of actors (Raynolds, 2009, p. 1086). The key operational principles of fair trade however, are to actively manage prices, credit arrangements, the duration of relationships and the level of North-South investment (Davenport and Low, 2012; Reed, 2012).

Overall, fair trade practices have received growing support from Northern stakeholders. Corporate brands and retailers have commercialised an increasing volume of certified goods (Doherty et al., 2012) and governments have supported fair trade through grant funding and their own procurement (Fisher, 2012). As a result, global retail sales of Fairtrade certified goods alone rose 12\% between 2010 and 2011, to $€ 4.9$ billion (Fairtrade International, 2012, p. 3), and sales of non-certified products

\footnotetext{
1 "Fairtrade" and "Fair Trade" are trademarked terms used in this article to refer to specific certification systems. By contrast, the (un-capitalised) term "fair trade" refers to the generic concept, often defined by key stakeholder as "a trading partnership, based on dialogue, transparency and respect, that seeks greater equity in international trade" (FINE, 2001, p. 1).
} 
have grown 40\% between 2001 and 2009 (Boonman et al., 2010, p. 23), with sales in dedicated fair trade shops topping $\$ 1$ billion (Doherty et al., 2012, p. 2).

Despite this success, fair trade has also been highly controversial. Some authors have suggested that certification fails to socially (re)connect actors (Dolan, 2010) or that fair trade offers only 'shaped advantage', "by which a limited number of producers enter the global market under more favourable terms, utilizing enhanced institutional capacity and marketing skills to tap into a growing niche market" (Lyon and Moberg, 2010, p. 8). In other cases, research even identifies significant contradictions between expected outcomes and empirical impact for specific producers and their organisations (Moberg, 2005). One of the most powerful critiques however, is premised on the view that prices emerge from the balance of supply and demand, and that therefore, the only means to increase returns to producers is to better balance these at the international level. Producers of low value goods are therefore expected to shift their efforts to the production of higher value alternatives (Collier, 2008; LeClair, 2002, p. 957). As a consequence, even when material benefits are realised by fair trade (for an example see: Utting, 2008), it is argued that this "retards the diversification of production that is fundamentally necessary for the economic advancement of developing countries" (LeClair, 2002, p. 957). Originally conceived for the production of handicraft goods, this critique has been extended to agricultural commodities exports (Sidwell, 2008) - the promotion of which also potentially threatens domestic food security (Brown, 2007) - and has been projected into public discourse in the mainstream media (See for example: Chambers, 2009; The Economist, 2006). In response, academics have proposed wider theoretical lenses that aim to re-embed analysis in the lived realities of trade relationships (Hayes, 2006, 
2008; Smith, 2009) - and therefore arguably sought to contribute towards freeing "policy imagination" from the ideological binaries that have tended to characterise debate around state strategies (Chang, 2012). Having said this, there has been no direct empirical investigation of how fair trade governance interacts with the diversification strategies of southern stakeholders.

Given the growing scale of fair trade activities, the current article responds to this shortfall in empirical understanding by critically analysing the experience of the National Smallholder Farmers' Association of Malawi (NASFAM). This organisation offers an insightful case study, as Malawi is in significant need of diversification away from agriculture (which contributes for 35 percent of GDP) and particularly reliance on tobacco exports that currently account for around 70 percent of foreign exchange (Booth et al., 2007, p. 6; Harrigan, 2003, p. 847; Malawian Government, 2009; Orr, 2000, p. 348; Tsutomu, 2009, p. 358). At the time of fieldwork, dealing with this structural situation was also greatly complicated by the persistent use of an overvalued exchange rate and on-going balance of payments crisis, as well as continuing concerns for food insecurity ${ }^{2}$.

To present this work, the paper first summarises the theoretical discussion of fair trade and diversification, and building on the call for more socially and geographically situated investigation, argues for the importance of considering the "moral geographies of food'. Following a discussion of the methodological and theoretical approach, the next section provides background on Malawi and NASFAM. The fifth and primary section then discusses NASFAM's experiences of fair trade in the

\footnotetext{
${ }^{2}$ It should be noted however, that since the completion of fieldwork, the government of Malawi has liberalised the country's exchange rate under pressure from the International Monetary Fund.
} 
marketing of groundnuts, produced by the Mchinji Area Smallholder Farmers' Association (MASFA), and Kilombero rice ${ }^{3}$, from the Kaporo Smallholder Farmers' Association (KSFA) (see Figure 1 for the physical geographical context of the study). Here it is argued that far from retarding diversification and structural change, fair trade has played a key role in building local and regional assets (of economic, social and physical capital), and facilitating a shift into higher value export markets without inherently threatening food security. Theoretically, analysis makes a wider contribution to understating how private agricultural certification might impact processes of diversification and broader structural change in certain contexts. More specifically, the article extends recognition of the importance, but also the weakness of 'social resources' embedded in the ethical identity supplied by fair trade (Doherty and Meehan, 2006 - see below); and specifically by reinterpreting these through the lens of 'moral geographies' and their role in the marketing of internationally traded goods.

\section{Fair Trade, Diversification and Structural Change}

Despite great popularity, there is on-going debate about the merits of fair trade. One critical discussion concerns the interaction between fair trade and the vital and interlinked development processes of 1) diversification into other economic activities (either because more diverse portfolios spread risk or new activities offer improved returns); 2) value chain upgrading (where actors graduate into functions of greater value adding and therefore larger returns); and 3) broader structural change (or

\footnotetext{
${ }^{3}$ Kilombero rice is a versatile and aromatic, long-grain variety of brown rice, eaten alongside maize as a staple food in northern Malawi.
} 
general transitions in the wider economy from low to higher value added activities) (Smith, 2009, pp. 459-460). In respect of these processes, critique grounded in neoclassical economic theory asserts that the payment of above market prices blunts the incentive for southern producers to diversify away from low value into higher return activities (See: LeClair, 2002, p. 956). This is especially pertinent as fair trade now works primarily within commodity agricultural where there is significant shortterm price volatility and arguably long-term real price decline vis-à-vis more highly processed and especially manufactured goods (Maizels, 1994; Ocampo and Parra, 2003; Prebisch, 1950). In other words, far from promoting the long-term interests of southern producers, fair trade might be perpetuating economic marginalisation in dead-end livelihoods that are likely to crash due to a lack of 'natural' market equilibrium. In this light, neoclassic analysis rejects fair trade 'interventions' in favour of allowing 'natural' price incentives to structure economic behaviour; and therefore, better promote economic development (Collier, 2008). In a related point, some have suggested that fair trade price interventions undermine domestic and regional food security (See discussion in Brown, 2007, p. 275) in an extension of the previously identified tensions of export-led-development - where producers themselves "speak of the contradictions of producing a product that is more or less useless in their local world" (Benson and Fischer, 2007, p. 807).

Alternatively, others reject the focus on price incentives as the only important variable in production decisions or that policy should further assume the universal presence of perfect markets (Hayes, 2008; Smith, 2009) - particularly given the well documented evidence to the contrary (de Janvry and Sadoulet, 2006; Obare et al., 2006; Stiglitz, 1989, p. 197). Instead, it is suggested that institutions are built to counter the real 
world obstacles to diversification and value chain upgrading within agrifood sectors, and in particular, the problems of producer 1) risk and uncertainty, and 2) limited endogenous capacity to respond to production possibilities (Smith, 2009, pp. 462465). Indeed, reference to wider micro economic research and theory suggests that for these reasons, where the poor diversify their livelihoods under distress push incentives, this often initiates for low-value, risk smoothing or coping activities, and not in pursuit of the higher-value accumulation propositions required for economic development (Bezemer et al., 2005; Kazianga and Udry, 2006). For this reason, it is argued that retracting interventions such as fair trade will still leave poor producers unlikely to add value and improve returns on economic activities (Smith, 2009, p. 459).

In support of this argument, it has long been held that fair trade can reduce livelihood vulnerability (Bacon, 2005) and build the material capacity of poor producers (Le Mare, 2008): to both increasingly manage risk (Ronchi, 2006) and respond to developmentally orientated incentives (Smith, 2009). This might apply within the same intra-generational area of production or wider inter-generational field through the funding of education, health or communication infrastructure (Arnould et al., 2009; Hayes, 2008, p. 2959; LeClair, 2008, p. 2964). This perspective helps counter the critique by arguing that upward pressure on prices, plus additional payment streams such as Social Premia, have the potential to build endogenous poducer capacity and, therefore, release structural bottlenecks ordinarily hindering diversification. In this way, fair trade can be viewed as working "in and against the market" (Brown, 1993), as it seeks to redress current inequalities of core economic capacity through existing economic relationships (See wider discussion of this issue 
in: Bassett, 2010). In an extension to the micro level of analysis, it can also be suggested that such support mechanisms have the potential to positively influence diversification at the wider macro level, as successful examples of this specifically highlight the important role often played by domestic, but especially international financial investment, the development of appropriate human capital and overarching coordination (Belwal and Chala, 2008; Mengistu, 2009). Furthermore, more recent work has identified that while some agricultural commodities remain in price decline, the appropriate social construction of such goods can reverse terms of trade balances at a more detailed level (Kaplinsky, 2006; Smith, 2009, p. 461). Unfortunately however, there is no significant empirical research into how such support facilitated by fair trade activities might influence the level of diversification in producer countries.

Another literature important to developing understanding of fair trade and diversification, is that concerning the 'moral geographies' of agrifood exports (Jackson et al., 2009; Morgan et al., 2006). More specifically, Goodman (2004, p. 894) provides an important focus for the current paper, observing that the commoditization of image associated with fair trade producers and practices "is crucial if not indispensable to the creation of the [trade] networks and the ir far-flung 'ethics of care"'. Narrowing the focus, Neilson and Pritchard (2010, p. 1844) extend their recognition of the value created by higher financial returns under Fairtrade certification, with the observation that "Fairtrade provides an additional point of brand differentiation" (Neilson and Pritchard, 2010, p. 1844); and conclude that the adoption of Fairtrade certification should be understood as part of a producer organisation's “overall agenda to position its brands and reputation to best effect within lucrative 
market segments" (Neilson and Pritchard, 2010, p. 1844). In this way, research highlights the importance of the "social resources", or the "intangibles such as a company's ethical and social standards [that] can be an attractive basis for differentiation [to]... business partners looking to position themselves on such a basis" (Doherty and Meehan, 2006, p. 303).

While these 'social resources' have not been considered in the discussion of fair trade and diversification they are recognised in wider analysis of export diversification. For example, mirroring the discussion above, Cramer (1999, p. 1251) identifies that building export markets for Southern agrifood products can be hindered by incumbent interests, political barriers, market structures and a lack of knowledge concerning the tastes of end consumers. However, just as mutually beneficial relationships with upstream foreign firms can provide support (arguably such as those developed through fair trade activity), it is also suggested that product differentiation via a clear branding strategy can play a significant role in the successful creation of nontraditional exports (Cramer, 1999).

Drawing on the above literature (in particular: Cramer, 1999; Hayes, 2008; LeClair, 2008; Smith, 2009), a framework has been developed to analyse the role of fair trade relationships established by a national scale producer cooperative. Principally, this has been achieved by combining emphasis on how fair trade governance contributes to stocks of physical, financial, human and social capital, with the previously unconsidered additions of marketing elements lent by the nature of fair trade relationships as part of the ir moral economy. The proposed framework is summarised in Table 1 below. 
[Table 1 about here]

\section{Case Studies and Research Methodology}

The remainder of the article analyses the case of how the National Smallholder Farmers' Association of Malawi (NASFAM) has utilised fair trade as a means to diversify its export portfolio, contribute towards the reduction of a significant balance of payments crisis, and also promote local food security. Specifically, the focus is placed on two embedded case studies of crops (see Map 1), both marketed through fair trade relationships as an overt part of NASFAM's diversification strategy: 1) groundnuts from the Mchinji Area Smallholder Farmers' Association (MASFA), exported via TWIN Trading into UK supermarkets and processed locally to develop value-added operations and promote food security; and 2) Kilombero rice grown and processed by the Kaporo Smallholder Farmers' Association (KSFA) and exported to Scotland via Just Trading Scotland (JTS) as a means to access non-traditional overseas markets.

[Figure 1: Map of Malawi showing location of NASFAM producer groups - about here]

In order to investigate these empirical examples fieldwork was conducted in Malawi during the 2009/2010 growing season. Data was captured through in-depth, key informant interviews with seven professional managerial and 30 farmer representatives of NASFAM from the national, regional and local Kaporo and 
Mchinji administrations. Interviews were also conducted with two government ministers (for trade and agriculture), three regional government representatives, five informants from partner trade and development support organisations (IMANI Development and TWIN Trading) and other relevant stakeholders. A further seven key informant interviews were conducted with representatives of NASFAM and other supply chain actors in the UK in 2012. Appropriate 'hard' and electronic documentary records and reports were also collected throughout the research process.

\section{The Impact of Historical Conditioning: The context for fair trade and diversification in Malawi}

In order to ground analysis of NASFAM's experience, it is necessary to provide context concerning Malawi and its relationship to the international political economy. A pertinent starting issue here is that the area of southern Africa, later known as Nyasaland and then Malawi, has become firmly connected with Britain: initially in 1859 through the celebrated Scottish medical missionary Dr. Livingstone, who had been sent to the region as a agent of Whitehall (McCracken, 2008, p. 55; Scottish Government, 2007). Immortalised in the famous greeting, "Dr. Livingstone I presume?" (supposedly delivered by Henry Morton Stanley when researching a story for the New York Herald), David Livingstone has emerged as an iconic figurer in both Britain and Malawi: a working-class Protestant missionary, who advocated the expansion of a commercial empire but importantly, simultaneously promoted the abolition of slavery based on an increasingly unfashionable belief in the equality of European and African populations (McCracken, 2008, p. 47). Following Livingstone's lead, other Scots, and particularly Scottish Presbyterian churches, were 
fundamental in establishing political and economic linkages embedded in a wider moral framework (McCracken, 2008). This is a relationship between Scotland and Malawi that has remained strong, and has been recently reasserted through Scotland's International Development Policy (Scottish Government, 2008) and the signing of the Scotland-Malawi Co-operation Agreement (Scottish Government, 2005).

The perceived value of a development partnership between Scotland and Malawi arises in part from the latter's designation as one of the poorest and least developed countries in the world. Despite the absence of violent conflicts, Malawi is ranked 171 out of 187 in the United Nations Human Development Index; 74 percent of the population live below the poverty line; and life expectancy is a meagre 54 years (OECD, 2008; United Nations, 2011). Over the years, geography and politics have combined to make economic development strikingly difficult in the country (Ellis et al., 2003; OECD, 2008). Malawi is landlocked, densely populated and has a highly inadequate transport and communication infrastructure (McCracken, 2008, p. 30). As the country has no endogenous oil, all petroleum based products have to be imported, strongly linking domestic inflation to the international economy (OECD, 2008, p. 405). In an attempt to mange this situation, the Malawian Kwacha (MK) has a long history of value adjustments (Kherallah et al., 2001, p. 26) and was pegged to the US Dollar between 2004 and 2012 (IMF, 2012). This strategy was highly beneficial in reducing import costs, and in particular, allowed the international sourcing of fertilisers, purchased and distributed as a core component of the government's celebrated food security programme (Dorward and Chirwa, 2011). However, the pegged currency also reduced export competitiveness and therefore lowered the inflow of foreign exchange (FOREX). Combined together, high spending on 
fertilizers and low FOREX reserves produced an ongoing balance of payments crisis. This greatly disadvantaged stakeholders reliant on others imports such as mineral fuels, as was hugely evident from the constant petrol shortages witnessed during fieldwork ${ }^{4}$.

Of further detriment to Malawi's development situation, is that the smallholder farmers - producing tobacco as a cash crop, and maize, beans, rice and cassava for consumption and sale (Action Aid International, 2006, p. 2) - who produce 70 per cent of all economic output and account for nearly 90 percent of the economically active population, have remained highly unproductive. As a result 70-80 percent of rural households run out of the staple food - maize - up to five months before the next harvest (Chinsinga, 2008, p. 1). This is partly due to a single short farming season, shrinking land per capita (due to an expanding population), declining soil fertility, and limited traction, fertiliser, irrigation and credit availability (Booth et al., 2007, p. 7; Dorward and Chirwa, 2011, pp. 232-233). On the more positive side however, the potential for positive change that these current problems create, means that agriculture continues to be viewed as "the most obvious means to stimulate broad-based rural growth and to provide levels of food security and income needed for the majority of the population" (Peters, 2006, p. 322) - and is a policy position that has resulted in the government's significant provision of inputs subsidies mentioned above.

A broader reason for the limited productivity of smallholder farmers however, has been the longstanding restrictions applied to their farming activities. Beginning with land appropriation by British settlers - especially for the cultivation of tobacco

\footnotetext{
${ }^{4}$ It should be noted that the overall balance of payments crisis subsequently led to the liberalisation and devaluation of the MK in May 2012.
} 
(McCracken, 1983; Milner, 2005, p. 46) - the colonial state restricted what, where, how much, and for what price, independent smallholders could sell most of their agricultural crops (Hazarika and Alwang, 2003, p. 100; Kydd and Hewitt, 1986, p. 1208). Even after Malawi's Independence in 1964, government policy continued to focus on plantation agriculture (Ellis et al., 2003, p. 3), and despite impressive macroeconomic performance (Chilowa, 1998, p. 554; Lele, 1990, p. 1209), smallholders were again granted little opportunity or benefit (Kydd and Christiansen, 1982; Sahn and Van Frausum, 1994).

The entrenched marginalisation of smallholders further continued despite extensive reforms demanded by international financial institutions in the 1980s. In fact, the removal of input subsidies and depreciation of the MK triggered sharp price increases for seeds and fertiliser that further reduced smallholder productivity, and greatly reducing food security. These stresses were compounded as the deconstruction of parastatal marketing services did not immediately promote private sector replacement of input provisions or market functions (Devereux and Tiba, 2007, p. 165; Dorward and Kydd, 2004; Milner, 2005, p. 53; Tsutomu, 2009, p. 359). Where private buyers did emerge, they were reportedly mostly unlicensed vendors benefiting from information asymmetries and fixing weights and measures; therefore building on a longer history of exploitative intermediaries (McCracken, 1983, p. 178; Ng'ong'ola, 1986). In more recent years, the development of the private sector has been intensified (Jayne et al., 2010, p. 13). However, despite this trend and the Government's flagship input subsidy programme, Malawi has remained food insecure and was hit by famines in 1991/1992, 2001/2002 (when between January and April, some 500-1,000 people 
died) and 2004/2005 (when more than one third of the population experienced food shortages) (Chinsinga, 2008; Menon, 2007, p. $1 \& 7$ ).

While the article returns to the issue of food security below, it is pertinent to note that due to historical conditioning, Malawi has been left with a legacy of agricultural dependence on a narrow range of crops; the significant marginalisation of smallholder farmers; and serious problems in feeding its population. As a result, wider analysis concludes that "markets are not the sole answer" (Peters, 2006, p. 322) and that “actions by state and civil society organisations...'regulated monopolies, regional commodity franchises, traders' associations, farmers' associations" (Peters, 2006, p. 342 My emphasis) are all key to the successfully promotion of development and food security in the country (Also see: Dorward and Kydd, 2004). In furthering this line of argument, the section below explores existing opportunities and specifically, some of those being explored by the country's largest farmers' association and their fair trade export partners based in European markets.

\section{The National Smallholder Farmers' Association of Malawi: 'Moral economy', diversification and development}

\subsection{The Emergence of NASFAM}

Unlike other African countries that have a longstanding tradition of 'native farmer' groups to promote a collective interest (FAO, 2010, pp. 37-38), in Malawi, such supports were confined to European settlers until the formation of the African Farmers Association in 1948 (McCracken, 1983, p. 191). More recently, in 1995 the United States Agency for International Development (USAID) funded a "Smallholder 
Agribusiness Development Project" (SADP) to work with existing smallholder clubs to strengthen their agri-business operations in response to the challenges arising from liberalising reforms of the 1980s (ACDI/VOCA, 2002, p. 5). The project aimed to improve grading and baling practices, and to organise collective transport and purchase of bulk inputs (Matchaya, 2010, p. 397).

Given the perceived success of the project, and as a further means to promote the collective interests of their members, the fourteen Associations established under SADP formed the National Smallholder Farmers' Association of Malawi (NASFAM) in 1998 (Chibonga, 2007; Walton, 2002, p. 1). In its current form, NASFAM is a bottom-up organisation within which individual farmers form clubs of 10 to 20 individuals. These clubs then come together in groups of 14 to form Management Association Committees (MACs), several of which in turn comprise a Local Association. Each level of the organisation is administered by a democratic committee that elects representatives - at least one of whom is a woman(Walton, 2002, p. 2) - to the next level and ultimately to the National Board - where, in contrast to many such organisations, no seats are taken by government officials (Poole and Frece, 2010, p. 69). The farmers' associations are registered individually under the Trustees Incorporation Act; they operate as corporate bodies and together form NASFAM as a whole (Matchaya, 2010, p. 398).

The key difference to previous support models in Malawi is that NASFAM is a private sector organisation, and although not registered as a cooperative, has many such characteristics (Bie and Lang, 2006, p. 3). Overall, the organisation comprises a non-taxable financial trust, NASFAM Corporate, and is owned by its c.100,000 farmer members - some 10 percent of Malawi's agricultural smallholder families who 
are not necessarily the poorest but potentially have a marketable surplus of produce (Bie and Lang, 2006, pp. 2-4; NASFAM, No Year, p. 3). Under the governance of the Nation Board, NASFAM has two subsidiaries. NASFAM Development is a registered trust, employing professional staff to deliver advice and technical support on crop selection and production, training on agronomic practices, and community development (NASFAM, No Year, p. 2). NASFAM Commercial, registered as an independent forprofit company, distributes seed at the start of the growing season and provides a guaranteed market at the end in order to facilitate the bulking of crops and secure access to the most profitable markets (NASFAM, No Year, p. 2 Interview: KSFA Employee 12/12/2009). Member farmers are paid a price derived from "cost of production analysis" based on data gathered from the field, and then agreed through the democratic institutions of the organisation (Interviews: KSFA Employee 12/12/2009; Government Extension Worker 10/12/2009; Farmer Surveys $)^{5}$. Another practice to promote the interests of members observed during fieldwork is the use of verified scales and transparent records for deliveries of inputs and purchases. From its inception NASFAM was intended to achieve financial sustainability, and despite initial support, operational costs are now covered by income from membership and post-harvest processing and marketing (Interviews: Kingsley Makiyoni 5/11/2009; Joshua Varela 5/11/2009; NASFAM Representatives 09/03/2012) ${ }^{6}$.

\footnotetext{
${ }^{5}$ It should be noted that this process of negotiation is not always smooth (Participation in association meeting; Bie and Lang, 2006, pp. 11-12).

${ }^{6}$ Complimentary projects are also funded by external donors for delivery by NASFAM - for example the diversification into animal husbandry (Direct observation and informal interview with farmers).
} 
Overall, NASFAM provides vertical integration to contribute to the alignment of individual actors along the value chain (Bijman et al., 2012, p. 82); and thereby compensates for the coordination failure common to developing world agriculture (Smith, 2009). In assessing the quality of such a contribution, independent analysis has been positive about NASFAM's activities and the organisation won the international Yara Prize ${ }^{7}$ in 2009 (Bie and Lang, 2006; Bie and Phiri, 2010, p. v, Poole and Frece, 2010).

[Figure 1: Structure of NASFAM about here]

\subsection{NASFAM, Diversification and Fair Trade Governance}

From the very beginning, one of the aims of the SADP investment was to establish a "an institutional framework...through which farmers could carry out their own agricultural development and diversification in a businesslike manner" (Walton, 2002, p. 1). Indeed, USAID had a specific aimed to support the Malawian government in promoting "crop diversification, away from the white maize" and tobacco, and to encourage the planting of other crops such as cassava (Devereux and Tiba, 2007, p. 152). For this reason, although NASFAM has been principally involved in tobacco, the organisation has always actively promoted livelihood diversification (Interviews: Joshua Varela 5/11/2009; NASFAM, No Year, p. 2) - an initiative that has became increasingly important given the growing limitations on Malawi's current and potential tobacco markets (Interviews: NASFAM Representative 09/03/2012;

\footnotetext{
${ }^{7}$ See the Yara Prize website (2012).
} 
Malawian Government Representative 4/11/2009) ${ }^{8}$. To operationalise this objective, although NASFAM's Associations initially focus on one particular crop, growers are supported in developing intercropping regimes (with a typical split of 60:40 between cash and food crops), and encouraged to look for other livelihood options: for example the adoption of small-scale retail trade in soft drinks (NASFAM, No Year, p. 2). At the national level, NASFAM has increasingly sought to promote new crops as well as geographically diversifying their international trade partners: for example, supporting the Zikometso Association in Mulanje to grow specialist 'bird's eye chilli peppers' for export to high value markets in Europe and Australia (Walton, 2002, p. $3)$.

Despite this prioritisation of diversification, the process has been slow, and in 2011 new initiatives only accounted for less than $10 \%$ of NASFAM's total revenue (Deraniyagala and Kaluwa, 2011, p. 6). One of the reasons for this is the extent to which the organisation was previously structured around the tobacco sector. Consequently, the level of investment needed to redirect operations is significant (Kherallah et al., 2001, pp. 27-28). This has been particularly true in the revival of Malawi's previously significant export performance in groundnuts. After decades of volatility, this export market crashed dramatically in the mid-1990s as a result of competition and widespread identification of Aflatoxin infection - a carcinogenic byproduct of ubiquitous fungi encouraged by poor husbandry as producers moisten the

\footnotetext{
${ }^{8}$ Demand for Malawian flue cured tobacco is in decline due to shrinking markets in Europe and North America, and limited possibilities for expansion in Asia due to consumer preferences (Deraniyagala and Kaluwa, 2011, p. 7; Nsiku and Botha, 2007, p. 10; Tobin and Knausenberger, 1998). The international donor community also increasingly decline support for tobacco production (Reuters
} Africa, 2010). 
nuts to facilitate easier shelling (Smith, 2011). As European Aflatoxin regulations were significantly tightened (Kherallah and Govindan, 1999, p. 132), Malawi lacked the capacity to respond swiftly and was forced to divert sales away from valuable European markets into domestic and regional alternatives (Minde et al., 2008, p. 42). As a result of this situation, previously significant exports to the UK were cut off entirely (Liberation Nuts, no date).

Under such conditions, it might be suggested that NASFAM should have abandoned attempts to export groundnuts to Europe and the UK market. However, there were very few alternatives available. As a NASFAM representative explained (Interview with anonymous representative $09 / 03 / 2012$ ), due to the historical conditioning of the country, there were very few crops that smallholder farmers could successfully produce. Sugar and tea were firmly controlled by estate interests and with increasing concerns about the profitability of tobacco - income from which collapsed in 2011 (Cammack, 2011, p. 7) - NASFAM considered their best option was to work with other cash crops: 1) familiar to smallholder farmers and 2) for which a certain level of marketing institutions was already established (Interview: Kingsley Makiyoni 5/11/2009). While this approach is supported by wider evidence that new export efforts tend to fail due to a lack of experience and infrastructure (Carletto et al., 2010), NASFAM were also conscious that groundnuts are consumed domestically: and therefore investing in the industry was not viewed to be contradictory to food security concerns.

As a result of this analysis, NASFAM continued to support members producing groundnuts, including those from the Mchinji Association (organised in the year 
2000). In parallel, in 1997, TWIN Trading, a London based not-for profit and dedicated fair trade import organisation, ${ }^{9}$ facilitated the setting up of Liberation Nuts: a UK based brand company, designed to provide direct access to UK and European markets for a variety of nuts originating in the developing world. Building on TWIN's experience setting up other dedicated fair trade companies, such as Divine Chocolate, Liberation Nuts was designed as a producer-owned organisation to ensure that farmers received 1) a stake in decision making, and 2) an automatic additional return when dividends are paid on their share holdings (for discussion see: Brown, 2007) ${ }^{10}$. As this organisation developed, TWIN identified that the situation of NASFAM, combined with its existing structure and nature of operation, made the producer organisation a prime potential trade partner for the Liberation Brand (Interview: Andrew Emmott 09/03/2012).

In 2003 a partnership began between NASFAM and TWIN with both parties sharing the objective of re-establishing a market for Malawian groundnuts in the UK. As a conventional commercial initiative, such a relationship would have made little sense given the likely limited return on the significant investment costs required. However, as TWIN Trading is dedicated to the construction of moral economy relations, the organisation saw additional value in rebuilding the trade partnership - and particularly with retailers such as The Cooperative, Tesco and Sainsbury's (Chibonga, 2012). To operationalise such relationships, TWIN and NASFAM worked together to obtain

\footnotetext{
${ }^{9}$ TWIN Trading has worked with the UK National Labelling Initiative of Fairtrade International to set up a Fairtrade nut standard.

${ }^{10}$ Liberation is $42 \%$ owned by producers in various African, Latin American and Asian countries (Interview: Andrew Emmott 09/03/2012).
} 
Fairtrade International certification for MASFA as a groundnut producing cooperative, and NASFAM itself as a registered exporter (Interviews: Kingsley Makiyoni 5/11/2009; Andrew Emmott 09/03/2012. Also see Fairtrade Foundation, 2008). In addition, TWIN brokered investment from the UK Department for International Development and the Comic Relief administered Fair Development Fund. Through this support, NASFAM has been able to invest in mechanical shelling equipment and develop the quality management systems needed to assess and mitigate Aflatoxin in the supply chain (TWIN Trading, 2012) ${ }^{11}$. As a result of such measures, the risk of future shipment rejection is reduced and it is easier to identify specific farmers' groups in which the problems of Aflatoxin need to be overcome (Adekunle et al., 2012, p. 50).

Once fair trade relations were established and NASFAM was selling into the UK through major supermarkets, the financial and physical capital of the organisation has been continually improved; although as other studies have shown, such material benefit is highly contingent on export volumes (See for example Bassett, 2010). Immediately after certification the tangible gains from the trade relationship established under Fairtrade certification were low, especially considering the upfront certification costs that NASFAM were required to pay (Interview with: Kingsley Makiyoni 5/11/2009). Having said this, as a result of the marketing role performed by northern partners, sales and therefore income from minimum payments and Social Premia have grown significantly. From 2007 to 2011 the rebuilding of groundnut

\footnotetext{
${ }^{11}$ This has been greatly helped by the development of low cost testing kits produced by the International Agriculture Research Centre for Semi-Arid Tropics (ICRISAT) (New Internationalist, 2011).
} 
exports to the UK provided a market for over 4,000 MASFA farmers (New Internationalist, 2011) and generated an income of $\$ 527,000$ and Fairtrade Premia to the value of $\$ 58,000{ }^{12}$. More specifically, in addition to the construction of a 'Guardian shelter' ${ }^{\prime 3}$ at Mchinjii's hospital, the Social Premium has been invested in processing and export capacity ${ }^{14}$ - and thus provides support for the theoretical argument that resources leveraged through fair trade networks can be used to invest in production capacity and quality improvement (Hayes, 2008; Smith, 2009). MASFA have also built one Community Buying Centre - that offers a small office with a safe, and a warehousing area that will further contribute to product quality - and have another building in progress. When these buildings are not being used for agricultural storage, they are utilised as a public space, and in some cases, are hired out as a further income stream for the producer Association. Finally, as also suggested in existing literature (Ronchi, 2006), fair trade relationships have provided greater stability for producer decision making; TWIN indicates its annual groundnut requirements each March, and thus allows NASFAM to plan projected incomes and marketing avenues (Interview: Kingsley Makiyoni 5/11/2009).

Due to these successes, NASFAM have sought to connect other Associations with fair trade markets in a way that also promotes the wider objective to increase the diversity of national exports. In this light, another particularly pertinent example of how fair trade has interacted positively with diversification in Malawi is through the export of

\footnotetext{
${ }^{12}$ Figures were calculated from NASFAM records.

${ }^{13}$ The Guardian shelter provides accommodation for visitors caring for patients at the hospital.

${ }^{14}$ Fairtrade standards require Social Premiums to be invested in democratically agreed, communal, development projects, and do not allow for direct distribution to individual farmers (Fairtrade International, 2011).
} 
Kilombero rice produced by KSFA. This is particularly pertinent as this product had not previously been exported to European consumer markets (Interview: Murdoch Gatward 22/06/2009). As in the case of groundnuts, this initiative was facilitated through the development of a relationship with another dedicated fair trade organisation, JTS (for details of this relationship see: Author, 2011). In this case, the fair trade nature of the buyer has seen the payment of 'fair prices' (as JTS has paid those necessary to cover the cost of sustainable production with appropriate livelihood surplus, the calculation of which have been openly discussed between the parties and seen by the research team) as well as the provision of direct funding for investment in export capacity.

When questioned about this initiative, Joshua Varela (NASFAM's Commercial Manager) returned to the fundamental issue of foreign exchange and the balance of payments crisis in the country. After noting the considerable detriment to both the national economy and the operations of his organisation, he continued:

"The FOREX needs sorting out, [for example] by exporting more rice to Scotland! That's one of the reasons that we want to make it work... We need to move away from the traditional exports, tobacco 500, 600 million dollars, that is more than half of the FOREX, I think, and a sane country should be running away from that situation. We can still maintain it at 600 million but that shouldn't be 50 percent of our exports. We need to look at how we can create a 300 million export market, a 200 million a 100 million etcetera". 
Indeed, NASFAM see the opportunities available through fair trade networks as a direct means of maintain and building non-traditional export markets; and furthermore, that the moral economy nature of fair trade means interactions offer better potential returns than conventional commercial opportunities. Like many southern agricultural marketing institutions, one of the principle problems of dealing with commodity agricultural goods is that they are traditionally only competitive on the basis of price (Interview: Joshua Varela 5/11/2009). However, some theory argues that even physically identical goods can be differentiated as unique products if they are embedded with extrinsic quality (Antle, 1999) in a way that that resonates with a particular consumer group (Callon et al., 2002). In line with such practices, NASFAM's management sees the opportunity to go beyond using "grades and standards as a tool for product differentiation" (Siambi et al., 2007, p. 124) and draw on the combination of geographic imagery and moral responsibility to develop a more powerful marketing proposition.

In the case of the Kilombero rice, the Commercial Manager sees a natural marketing advantage as it has "got a story behind it: small scale farmers behind a rift valley lake, where the dinosaurs used to live, you can create a good story, you can brand it" (Interview: Joshua Varela 5/11/2009). On one hand, this case might be taken as an example of how commercialisation plays into the commodification of identity and a consumer fascination with exotic and foreign places (Bell and Valentine, 1997). Indeed, some have argued for a "double commodity fetish" of foodstuffs: an ignorance of the origin and conditions of production of the desired items combined with geographical "lore" about these origins (Cook and Crang, 1996). However, in identifying the location of the cultural construction of food in the supply chain (See: 
Jackson et al., 2009), the active agency of Malawian based stakeholders must be recognised, and this adds nuance to interpretations that focus on the 'objectification' of 'poor', 'exotic' food producers by European and North American marketing ${ }^{15}$. Indeed, revealing the involvement of Southern actors in the social construction of export products might well begin to answer the call for "forms of critical intervention that work with the fetish rather than attempt to reach behind it" (Cook and Crang, 1996, p. 131).

Beyond this hwever, the nature of NASFAM as a democratic producer organisation has provided the opportunity for the formation of fair trade relationships; and through this, the embedding of morality and responsibility within geographic representation. As is recognised by stakeholders in the supply system "obviously fair trade provides a great market angle" in the UK and particularly Scotland (Interviews: IMANI Representative 22/06/2009; and independent marketing consultant based in Malawi 24/11/2009). Indeed, in presenting the Kilombero rice, JTS is able to draw on resources of geographic representation as well as the historical connections between places and the aspirations of Scotland to be a Fair Trade Nation ${ }^{16}$ (see for example: JTS, 2012).

Likewise, NASFAM's groundnut have been marketed under the Liberation brand: which has been identified as instrumental in re-building the groundnut industry in Sub-Saharan Africa, particularly in Malawi, and therefore reintroducing Malawian nuts back into the global market (Personal Communication with Independent

\footnotetext{
${ }^{15}$ Also see Guthman (2003) and for a specific discussion of fair trade, Berlan (2008).

${ }^{16}$ For a discussion of the Fair Trade Nation programme see Fisher (2012) and Author (In Press).
} 
Consultant 27/01/2012). Identifying the importance of fair trade as a marketing element, NASFAM's Chief Executive Officer (CEO) considers that Malawian groundnuts would have never re-entered the UK market had it not been for the opportunity offered through the partnership with TWIN, or FLO certification for which there is now considerable demand in European markets (Interview: Dybon Chiabonga 16/09/2010). Indeed, according to those actually involved in negotiations with UK supermarkets:

"The fair-trade proposition provided a platform. It gave people an opportunity to have dialogue about what we were trying to do about establishing a route to market. I think if you just tried to do that with a new geographic origin...given that you've got some major brands that you'd be competing against, I think it would be very difficult to get any communication around that without something like the fair trade message" (Interview: Andrew Emmott 09/03/2012).

This testimony from the perspective of a producer organisation supports conclusions elsewhere, that in addition to physical resources returned through higher prices and the social premium, fair trade operation can also contribute to the social construction of products - potentially otherwise unable to find such a profitable market position. However, where marketing analysis of retail sales has tended to treat the 'social resources' of ethical identity as abstract assets, this overlooks their implicit and explicit embedding in underlying understandings of moral geographies: where 'geographical knowledges' are created through the transformation of 'spaces' into 'places', and interconnected through morally grounded relationships based on their respective identities in a framework of "relational ethics" (Goodman, 2004; 
Whatmore, 1997). Instead, analysts and practitioners must take care to recognise the importance of 'place' in the social construction of fair trade products. While this is to a large extent fundamentally embedded in the fair trade concept (as at the current time it is used almost exclusively in relation to South-North trade) more specific geographical representations, often differentiated by a focus on a particular national context and its popular imagination, might be fundamental to successful international marketing strategies. In this way, a focus on moral geographies within fair trade reinforces the suggestion that, far from offering a universal mechanism to improve the opportunity of Southern producers, fair trade provides only geographically concentrated or 'shaped advantage'. In the case of NASFAM, for example, although the organisation is aware of the importance of geographical imagery, exports to Scotland have been built on a specific longstanding historical relationship, reinforced in the contemporary understanding of stakeholders through the recent establishment of the Scotland-Malawi Partnership.

In addition to the social resources useful to generate market access to Europe, more nuanced 'geographical knowledges' held by dedicated fair trade organisations arguably owing to their close working relationship with producer communities - can also facilitate partnership activities that go beyond market access initiatives. In the case of TWIN Trading and JTS, these additional initiatives have included both efforts to expand the amount of value added in the producer country, but also to address potential tensions generated by the desires for export-led growth and domestic food security (See: Brown, 2007). As noted above, JTS have invested directly in production capacity and specifically have funded a rice cleaning and bagging plant in Karonga. As well as increasing the amount of value that can be added by the producer 
community themselves (where previously, the process had to be carried out by a company in the UK), it also allows the Association to produce a high quality product for the local market into which the majority of the member's crop is directed (without using costly third party processors elsewhere in the country).

In the case of NASFAM's fair trade relationship with TWIN, the two organisations have also launched a groundnut processing business called Afri-Nut Ltd - by leveraging additional investment from the further shareholders of Ex-Agris (a commercial agricultural company with interests in Malawi), Cordaid (a Dutch donor organisation) and the Waterloo Foundation (an environmentalist trust based in Wales). The company's factory in Malawi's capital, Lilongwe, was opened at the end of 2011 with the ability to process $4,000 \mathrm{MT}$ of nuts a year: all of which meet the standards of Europe's Aflatoxin regulations (due to an on-site aflatoxin test laboratory) and Fairtrade certification requirements (Interview: Andrew Emmott 24/01/2012; also see TWIN Trading, 2012). Furthermore, with the ability to add value to raw groundnuts, through processes of blanching and roasting, the project provides a concrete example of dedicated fair trade partnerships facilitating the pragmatic value chain upgrading central to economic development. According to the most recent figures Afri-Nut performed well in the first year of operation, providing a market for some 1,000MT of groundnuts, employing 60 workers and almost reaching the breakeven point (Personal Communication with Project Facilitator 23/01/2013).

In addition to this upgrading, the Afri-nut venture has also been designed with the conscious recognition of wider issues. This is because TWIN representatives acknowledge that at some point, Northern fair trade markets are ultimately limited, 
and that therefore Southern producers need to identify alternative, and ideally high value and diversified markets within the Global South itself. The organisation has also been concerned that Aflatoxin is mainly considered as an export issue - thus leading to the redirection of toxins into local markets - and not one of public health, wider development and capacity building in the Global South. For this reason, the new venture is specifically intended as a hub of safe, domestic processing, for groundnuts entering the local and regional economy. Furthermore, in order to develop higher value added operations targeted at intra-continental markets, Afri-nut is embarking on the production of the therapeutic food, 'plumpy nut' (Personal Communication with Independent Consultant 27/01/2012). This 'Ready to Use Therapeutic Food' (RUTF) is a high-energy, high-protein mixture developed in 1999 and first introduced in 2005, and is used to feed malnourished children and HIV/AIDS patients undergoing retroviral treatment throughout Africa. The intention is that the Afri-Nut facility will integrate into the existing multifunctional approach of stakeholders to supply peanut paste to local producers such as Valid Nutrition or Project Peanut Butter: and will then in turn supply therapeutic food to international aid agencies such as UNICEF (Smith, 2011).

In this way, the case study of NASFAM offers a counter narrative to that which suggests fair trade activities will necessarily be at the expense of domestic food security. Furthermore, the example supports the argument that capacity developed for the management of international supply chains can also enhance the production of food for the local market (See: Mathew, 2011). Unfortunately, however, there remains a lot of work to be done in this area. It is estimated that around $60 \%$ of peanuts in Malawi do not enter formal supply chains and therefore the majority are processed 
and consumed without consideration of the significant risks to long-term human health. When this issue is placed in the global context it is estimated that 4.5 billion people in developing countries are at risk of chronic exposure to Aflatoxin through contaminated foods (Shephard, 2003). For this reason, TWIN Trading have an ongoing concern to widen the scope of their investment in Malawian infrastructure (Interview: Andrew Emmott 24/01/2012) - and such activity should be an important area for research in the future.

\section{Conclusions}

The article has attempted to open up "policy imagination" (Chang, 2012) concerned with agricultural development in the Global South, and more specifically, to provide empirically grounded analysis of the relationship between fair trade certification and producer diversification. Critically analysing the case of the National Smallholder Farmers' Association of Malawi, overall the case supports existing theory that holds diversification opportunities for southern agricultural producers are not freely available or easily operationalised - and thereby supports efforts to develop alternative, more inductively informed theoretical frameworks of evaluation (Smith, 2009). Although Malawi has been a substantial exporter of groundnuts in the past, the lack of economic development prevented the necessary response to the negative shock of aflatoxin and declining demand. Despite this narrowing of opportunities, the management of NASFAM reports that they have found few realistic alternative exports to promote. Indeed, diversification decisions have been informed by a lack of endogenous capacity (in terms of the general development situation in Malawi and the limited knowledge of farmers and marketing institutions) and the perceptions of risk 
associated with alternative projects (linked back to the lack of capacity and precarious economic and food security situation). Therefore, as predicted by Smith (2009), 'pus h incentives' to exit traditional sectors have not necessarily been matched by the availability of alternative sectors, or 'pull incentives', to invest in other crops and marketing approaches.

Furthermore, the case supports the argument that in such a context, fair trade relationships can offer access to the important social, economic and physical capital, necessary to maintain and expand exports (Hayes, 2008; Smith, 2009). While involvement in fair trade networks contributed to NASFAM's social capital (or supportive networks), accessed via relationships with TWIN and JTS, these connections then led to economic and physical investments from a variety of organisations. Once operational trade relationships were constructed, resource injections have continued through the governance relationship established by Fairtrade International certification (for groundnuts) and the fair trade principles applied by JTS (buying Kilombero rice). Fair trade networks have even directly invested in infrastructure which improves the ability of NASFAM to supply local markets: and therefore the case also offers a counter narrative to the assumed contradiction between fair trade and domestic food security. Beyond these issues, however, the case highlights the importance of considering resources supplied by 'moral geographies' within analysis of diversification. As identified in the political economy literature (for example: Cramer, 1999, p. 1251), marketing plays a central role in the success of non-traditional exports. Here, although NASFAM has drawn on the geographical origin of products, they have also consciously embedded the fair trade nature of production and trade conditions as part of their wider identity. 
On this basis, the article concludes that fair trade relationships can offer real possibilities for maintaining and expanding value-added export portfolios; as while reducing direct contradictions with domestic food security concerns. Having said this, the nature of research as a case study limits what can be said about fair trade governance as a wider phenomenon - and certainly does not overcome the interpretation of fair trade as offering "shaped advantage" to only particular producers able to access such networks (Lyon and Moberg, 2010, p. 8). Indeed, refining the consideration of ethical marketing through a lens of moral geographies highlights that some producer countries will be better positioned to leverage 'social resources' than others - and the relationship between Malawi and Scotland underscores the specificity of this example. Furthermore, in contrast to the majority of fair trade producers, NASFAM has partnered with 'dedicated' or 'mission driven' fair trade organisations (TWIN and JTS). Although there are some exceptions (See: Fairtrade Foundation, 2012b; Weru, 2012), wider evidence from commercial supply chains suggests profit orientated fair trade buyers have less interest in investing in producer capacity (Raynolds and Ngcwangu, 2010Raynolds and Ngcwangu, 2010). For these reasons, it is of geat importance that research continues to investigate the effects of fair trade activity on diversification and upgrading, but within a sufficiently nuanced understanding of varied commitment and practice within the movement as a whole. Indeed, the key focus of future work must be on transferring knowledge of successful fair trade operations, within, and ideally beyond, the boundaries of fair trade activities as they are recognised today. 


\section{Bibliography}

ACDI/VOCA, 2002. NASFAM Strengthening Project (NSP) Malawi: Quarterly Report.

Action Aid International, 2006. Climate Change and Smallholder Farmers in Malawi: Understanding poor people's experiences in climate change adaptation. ActionAid, Johannesburg.

Adekunle, A., Ellis-Jones, J., Ajibefun, I., Nyikal, R., Bangali, S., Fatunbi, O., Ange, A., 2012. Agricultural Innovation in Sub-Saharan Africa: Experiences from MultipleStakeholder Approaches

Forum for Agricultural Research in Africa, Accra, Ghana.

Antle, J.M., 1999. The new economics for agriculture. American Journal of Agricultural Economics 81, 993-1010.

Arnould, E.J., Plastina, A., Ball, D., 2009. Does Fair Trade Deliver on Its Core Value Proposition? Effects on Income, Educational Attainment, and Health in Three

Countries. Journal of Public Policy \& Marketing 28 (2), 186-201.

Author, 2011.

Author, in press.

Bacon, C., 2005. Confronting the Coffee Crisis: Can Fair Trade, Organic, and Specialty Coffees Reduce Small-Scale Farmer Vulnerability in Northern Nicaragua? World Development 33 (3), 497-511.

Barrientos, S., Dolan, C., 2006. Ethical Sourcing in the Global Food System. Earthscan, London

Bassett, T.J., 2010. Slim Pickings: Fairtrade cotton in West Africa. Geoforum 41 (1), 44-55.

Bell, D., Valentine, G., 1997. Consuming geographies : we are where we eat. Routledge, London; New York.

Belwal, R., Chala, M., 2008. Catalysts and barriers to cut flower export. International Journal of Emerging Markets 3 (2), 216-235.

Benson, P., Fischer, E.F., 2007. Broccoli and Desire. Antipode 39 (5), 800-820.

Berlan, A., 2008. Making or marketing a difference? An anthropological examination of the marketing of fair trade cocoa from Ghana, in: Neve, G.D., Peter, L., Pratt, J., Wood, D.C. (Eds.), Hidden Hands in the Market: Ethnographies of Fair Trade, Ethical Consumption, and Corporate Social Responsibility. Emerald, Bingley, pp. 171-194.

Bezemer, D., Balcombe, K., Davis, J., Fraser, I., 2005. Livelihoods and farm efficiency in rural Georgia. Applied Economics 37 (15), 1737-1745.

Bie, S., Lang, T., 2006. Evaluation of Norwegian support to NASFAM's Strategic

Development Programme 2001-2006. Noragric: Norwegian University of Life

Sciences, Aas, Norway.

Bie, S.W., Phiri, S., 2010. Mid-term review of the strategic development programme 2006-2011 (SDP2) of the National Smallholder Farmers' Association of Malawi (NASFAM).

Bijman, J., Muradian, R., Cechin, A., 2012. agricultural Cooperativs and Value Chain Coordination, in: Helmsing, A.H.J., Vellema, S. (Eds.), Value Chains, Social Inclusion and Economic Development. Routledge, Abingdon, UK, pp. 82-103. Boonman, M., Huisman, W., Sarrucco-Fedorovtsjev, E., Sarrucco, T., 2010. Fair Trade Facts and Figures: A Success story for Producers and Consumers. Dutch Association of Worldshops (DA WS), Culemborg, The Netherlands. 
Booth, D., Cammack, D., Harrigan, J., Kanyongolo, E., Mataure, M., Ngwira, N., 2007. Drivers of Change and Development in Malawi, Working Paper. Overseas Develompent Institute, London.

Brown, M.B., 1993. Fair Trade: Reform and realities in the international trading system. Zed Books, London.

Brown, M.B., 2007. "Fair Trade" with Africa. Review of African Political Economy 34 (112), 267-277.

Callon, M., Eacute, Adel, C., Rabeharisoa, V., 2002. The Economy of Qualities. Economy and Society 31, 194-217.

Cammack, D., 2011. Malawi's political settlement in crisis. Africa, Power and Politics, London

Carletto, C., Kirk, A., Winters, P.C., Davis, B., 2010. Globalization and Smallholders: The Adoption, Diffusion, and Welfare Impact of Non-Traditional Export Crops in Guatemala. World Development 38 (6), 814-827.

Chambers, A. 2009. Not so fair trade [Online]. http://www.guardian.co.uk/commentisfree/cif-green/2009/dec/12/fair-trade-fairtradekitkat-farmers. Accessed: 02/06/2012.

Chang, H.-J., 2012. Public Policy and Agricultural Development ISS Studies in Rural Livelihoods. Routledge, Abingdon, UK.

Chibonga, D., 2007. Linking Farmers to Markets: Prospects and Challenges Learned from NASFAM, An International Workshop on "Strengthening and Widening Marketsand Overcoming Supply Side Constraints for African Agriculture", Taj Pamodzi Hotel, Lusaka, Zambia.

Chibonga, D., 2012. Partnership for Smallholder Development to Access Markets, Seminar Presentation, ICRISAT Headquarters, Hyderabad, India.

Chilowa, W., 1998. The Impact of Agricultural Liberalisation on Food Security in Malawi. Food Policy 23 (6), 553-569.

Chinsinga, B., 2008. The Malawi Fertiliser Subsidy Programme: Politics and pragmatism, in: Hughes, D. (Ed.), Policy Briefing. Future Agricultures.

Clark, M.R., Kozar, J.S., 2011. Comparing Sustainable Forest Management

Certifications Standards: A meta-analysis. Ecology and Society 16 (1).

Collier, P., 2008. The Bottom Billion: Why the poorest countries are failing and what can be done about it. Oxford University Press, Oxford.

Cook, I., Crang, P., 1996. The World On a Plate: Culinary Culture, Displacement and Geographical Knowledges. Journal of Material Culture 1 (2), 131-153.

Cramer, C., 1999. Can Africa Industrialize by Processing Primary Commodities? The Case of Mozambican Cashew Nuts. World Development 27 (7), 1247-1266.

Davenport, E., Low, W., 2012. The World Fair Trade Organization: From trust to compliance, in: Reed, D., Utting, P., Mukherjee-Reed, A. (Eds.), Business Regulation, Non-State Actors and Development: Whose Standards? Whose Development?

Routledge, London.

de Janvry, A., Sadoulet, E., 2006. Progress in the Modeling of Rural Households' Behaviour under Market Failures, in: de Janvry, A., Kanbur, R. (Eds.), Poverty, Inequality and Development, Essays in Honor of Erik Thorbecke. Springer, New York.

Deraniyagala, S., Kaluwa, B., 2011. Macroeconomic policy for employment creation: The case of Malawi Employment Working Paper. International Labour Organization. Devereux, S., Tiba, Z., 2007. Malawi's First Famine, 2001-2002, in: Devereux, S. (Ed.), The New Famines: Why famines persist in an era of globalization. Routledge, London and New York, pp. 143-177. 
Doherty, B., Davies, I.A., Tranchell, S., 2012. Where now for fair trade? Business History, 1-29.

Doherty, B., Meehan, J., 2006. Competing on social resources: the case of the Day Chocolate Company in the UK confectionery sector. Journal of Strategic Marketing 14 (4), 299-313.

Dolan, C.S., 2010. Virtual Moralities: The mainstreaming of Fairtrade in Kenyan tea fields. Geoforum 41 (1), 33-43.

Dorward, A., Chirwa, E., 2011. The Malawi Agricultural Input Subsidy Programme: 2005-6 to 2008-9. International Journal of Agricultural Sustainability 9 (1), 232-247.

Dorward, A., Kydd, J., 2004. The Malawi 2002 food crisis: the rural development challenge. The Journal of Modern African Studies 42 (03), 343-361.

Ellis, F., Kutengule, M., Nyasulu, A., 2003. Livelihoods and Rural Poverty Reduction in Malawi. World Development 31 (9), 1495-1510.

Exagris Africa 2013. About Exagris Africa Limited [Online].

http://www.exagrisafrica.com/about-us.html. Accessed: 02/04/2013.

Fairtrade Foundation 2008. Mchinji Area Smallholder Farmers Association (MASFA), Malawi [Online]. http://www.fairtrade.org.uk/producers/nuts/masfa malawi.aspx. Accessed: 01/02/2010.

Fairtrade Foundation, 2012a. Making international supply chains work for smallholder farmers: A comparative study of six fair trade value chains. Fairtrade Foundation, London.

Fairtrade Foundation, 2012b. Taking Control of the Supply Chain, Fair Comment. Fairtrade International, 2011. Fairtrade Standard For Small Producer Organizations, Bonn. Fairtrade International,.

Fairtrade International, 2012. For Producers, With Producers: Annual Report 2011-12. Fairtrade International, Bonn, Germany.

FAO, 2010. A Review of Existing Organisational Forms of Smallholder Farmers' Associations and their Contractual Relationships with other Market Participants in the East and Southern African ACP Region, AAACP Paper Series. Food and Agriculture Organization of the United Nations, Rome.

FINE, 2001. Fair Trade Definition and Principles. Fair Trade Advocacy Office, Brussels.

Fisher, E., 2012. The 'Fair Trade Nation': Market-Oriented Development in Devolved European Regions? . Human Organisation 77 (3), 255-267.

Goodman, M.K., 2004. Reading Fair Trade: Political ecological imaginary and the moral economy of fair trade foods. Political Geography 23 (7), 891-915.

Guthman, J., 2003. Fast food/organic food: Reflexive tastes and the making of "yuppie chow. Social and Cultural Geography 4 (1), 45-58.

Harrigan, J., 2003. U-Turns and Full Circles: Two decades of agricultural reform in Malawi 1981-2000. World Development 31 (5), 847-863.

Hayes, M., 2006. On the efficiency of fair trade. Review of Social Economy 64 (4), 44-468.

Hayes, M., 2008. Fighting the Tide: Alternative trade organizations in the era of global free trade - A comment. World Development 36 (12), 2953-2961.

Hazarika, G., Alwang, J., 2003. Access to Credit, Plot Size and Cost Inefficiency Among Smallholder Tobacco Cultivators in Malawi. Agricultural Economics 29 (1), 99-109.

IMF, 2012. IMF Country Report: Malawi. IMF, Washington D.C.

Jackson, P., Ward, N., Russell, P., 2009. Moral economies of food and geographies of responsibility. Transactions of the Institute of British Geographers 34 (1), 12-24. 
Jayne, T.S., Sitko, N., Ricker-Gilbert, J., Mangisoni, J., 2010. Malawi's Maize Marketing System. School of Oriental and African Studies, London.

JTS 2012. Celebrating the World's Harvest [Online]. http://www.justtradingscotland.co.uk/pages/90kg-challenge-harvest-church.

Kaplinsky, R., 2006. Revisiting the revisited terms of trade: Will China make a difference? World Development 34 (6), 981-995.

Kazianga, H., Udry, C., 2006. Consumption smoothing? Livestock, insurance and drought in rural Burkina Faso. Journal of Development Economics 79, 413-446.

Kherallah, M., Govindan, K., 1999. The sequencing of agricultural market reforms in Malawi. Journal of African Economies 8 (2), 125-151.

Kherallah, M., Minot, N., Kachule, R., Soule, B.G., Berry, P., 2001. Impact of Agricultural Market Reforms on Samllholder Farmers in Benin and Malawi.

International Food Policy Research Institute, the University of Hohenheim, and Collaborating African Institutions.

Kydd, J., Christiansen, R., 1982. Structural Change in Malawi Since Independence: Consequences of a development strategy based on large-scale agriculture. World Development 10 (5), 355-375.

Kydd, J., G, Hewitt, A., 1986. The Effectiveness of Structural Adjustment Lending: Initial evidence from Malawi. World Development 14 (3).

Le Mare, A., 2008. The Impact of Fair Trade on Social and Economic Development: A review of the literature. Geography Compass 2 (6), 1922-1942.

LeClair, M.S., 2002. Fighting the Tide: Alternative trade organizations in the era of global free trade. World Development 30 (6), 949-958.

LeClair, M.S., 2008. "Fighting the Tide: Alternative Trade Organizations in the Era of Global Free Trade"-A Reply. World Development 36 (12), 2962-2965.

Lele, U., 1990. Structural Adjustment, Agricultural Development and the Poor: Some lessons from the Malawian experience. World Development 18 (9), 1207-1219. Liberation Nuts no date. Meet the Farmers in Malawi [Online]. http://www.chooseliberation.com/malawi.html.

Low, W., Davenport, E., 2006. Mainstreaming Fair Trade: Adoption, assimilation, appropriation. Journal of Strategic Marketing 14 (4), 315 - 327.

Lyon, S., Moberg, M., 2010. Fair Trade and Social Justice: Global ethnographies. New York University Press, New York.

Maizels, A., 1994. The continuing commodity crisis of developing countries. World Development 22 (11), 1685-1695.

Malawian Government 2009. Malawi President Threaten to Arrest Expelled Tobacco Buyers [Online]. http://www.malawi.gov.mw/story.php?id=326. Accessed:

24/08/2010.

Matchaya, G., 2010. Cooperative patronage: The National Smallholder Farmers' Association of Malawi in Kasungu District. Development Southern Africa 27 (3), 397-412.

Mathew, T., 2011. Tricky Waters, in: Bowes, J. (Ed.), The Fair Trade Revolution. Palgrave, London, pp. 173-186.

McCracken, J., 1983. Planters, Peasants and the Colonial State: The Impact of the Native Tobacco Board in the Central Province of Malawi. Journal of Southern African Studies 9 (2), 172-192.

McCracken, J., 2008. Politics and Christianity in Malawi 1875-1940: The Impact of the Livingstonia Mission in the Northern Province. Kachere Series, Zomba, Malawi. 
Mengistu, A.A., 2009. Do Physical and Human Capital Matter for Export Diversification?: A Comparative Analysis of Sub-Saharan Africa and East Asia. African and Asian Studies 8 (1-2), 1-46.

Menon, R., 2007. Famine in Malawi: Causes and consequences, Occassion Paper. Human Development Report Office.

Milner, J., 2005. Agricultural and Rural Development in Malawi: The role of policies and policy processes, in: Takane, T. (Ed.), Agricultural and Rural Development in Malawi: Macro and Micro Perspectives. Institute of Developing Economies, Japan External Trade Organization.

Minde, I., Madzonga, O., Kantithi, G., Phiri, K., Pedzisa, T., 2008. Constraints, Challenges, and Opportunities in Groundnut Production and Marketing in Malawi. Research Report. International Crops Research Institute for the Semi-Arid Tropics. Moberg, M., 2005. Fair Trade and Eastern Caribbean Banana Farmers: Rhetoric and reality in the anti-globalization movement. Human Organization 64 (1), 4-15.

Morgan, K., Marsden, T., Murdoch, J., 2006. Worlds of Food: Place, power, and provenance in the food chain, Oxford Geographical and Environmental Studies. Oxford University Press, Oxford.

Moudud, J., Botchway, K., 2007. Challenging the orthodoxy: African development in the age of openness. African and Asian Studies 6 (4), 457-493.

NASFAM, No Year. National Smallholder Farmers Association of Malawi (Informational Leaflet). NASFAM, Lilongwe.

Neilson, J., Pritchard, B., 2010. Fairness and Ethicality in their Place: The regional dynamics of fair trade and ethical sourcing agendas in the plantation districts of South India. Environment and Planning A 42 (8), 1833-1851.

New Internationalist, 2011. Peanut Farmers Back in Business. May (442).

Ng'ong'ola, C., 1986. Malawi's Agricultural Economy and the Evolution of Legislation on the Production and Marketing of Peasant Economic Crops. Journal of Southern African Studies 12 (2), 240-262.

Nicholls, A., Opal, C., 2005. Fair Trade: Market-driven ethical consumption. Sage, London.

Nsiku, N., Botha, W., 2007. Tobacco Revenue Management: Malawi case study. International Institute for Sustainable Development.

Obare, G.A., Shiferaw, B.A., Muricho, G., 2006. Strategic Assessments and Development Pathways for Agriculture in the Semi- Arid Tropics: Leveraging Rural Institutions for Collective Action to Improve Markets for the Poor: Lessons and Policy Options, Policy Brief. International Crops Research Institute for the Semi- Arid Tropics, Andhra Pradesh, India.

Ocampo, J.A., Parra, M.A., 2003. Returning to an Eternal Debate: The Terms of Trade for Commodities in the Twentieth Century. . United Nations Publications, Santiago.

OECD, 2008. Malawi, African Economic Outlook. OECD, Paris, pp. 399-413. Orr, A., 2000. 'Green Gold'?: Burley tobacco, smallholder agriculture and poverty alleviation in Malawi. World Development 28 (2), 347-336.

Peters, P.E., 2006. Rural income and poverty in a time of radical change in Malawi. The Journal of Development Studies 42 (2), 322-345.

Poole, N., Frece, A.d., 2010. A Review of Existing Organisational Forms of Smallholder Farmers' Associations and their Contractual Relationships with other Market Participants in the East and Southern African ACP Region. Trade and Markets Division, FAO, Rome. 
Prebisch, R., 1950. The Economic Development of Latin America and Its Principal Problems. Economic Bulletin for Latin America 7, Unknown.

Raynolds, L., 2009. Mainstreaming Fair Trade Coffee: From partnership to traceability. World Development 37 (6), 1083-1093.

Raynolds, L.T., Ngcwangu, S.U., 2010. Fair Trade Rooibos Tea: Connecting South African producers and American consumer markets. Geoforum 41 (1), 74-83.

Reed, D., 2012. Fairtrade International (FLO), in: Utting, P., Reed, D., Reed, A.

(Eds.), Business Regulation and Non-State Actors Whose Standards? Whose

Development? Routledge, London.

Reuters Africa 2010. African Farmers Fear Tobacco Curb "Catastrophe" [Online]. http://af.reuters.com/article/topNews/idAFJOE6A30CT20101104. Accessed: 06/11/2010.

Ronchi, L., 2006. Fairtrade' and market failures in agricultural markets, World Bank Policy Research Working Paper 4011. World Bank, New York.

Sahn, D.E., Van Frausum, Y., 1994. Economic Growth, Income Distribution and Agricultural Policy in Malawi. Journal of African Economy 3 (3), 412-446.

Scottish Government, 2005. Scotland Malawi Co-operation Agreement. Scottish Government.

Scottish Government 2007. Dr David Livingstone [Online].

http://www.scotland.gov.uk/Topics/Government/International

Relations/internationaldevelopment/malawi/davidlivingstone. Accessed: 12/03/2010. Scottish Government, 2008. International Development Policy.

Shephard, G.S., 2003. Aflatoxin and Food Safety: Recent African Perspectives. Toxin Reviews 22 (2-3), 267-286.

Siambi, M., Estrada, J., Jones, R., Malawi, N.S.F.A.o., 2007. Overcoming Market Challenges for Smallholder Farmers: The case of groundnuts in Malawi, in: Nærstad, A. (Ed.), Africa Can Feed Itself The Development Fund, Oslo.

Sidwell, M., 2008. Unfair Trade. Adam Smith Institute, London.

Smith, A.M., 2008. 'The Fair Trade Cup is 'Two-Thirds Full' not 'Two-Thirds

Empty":: A response to the Adam Smith report \& a new way to think about measuring the content of the fair trade Cup, Comment and Analysis. ESRC Centre for Business Relationships, Accountability, Sustainability and Society. Cardiff University.

Smith, A.M., 2009. Fair Trade, Diversification and StructuralChange: Towards a broader theoretical framework of analysis. Oxford Development Studies 37 (4), 457478

Smith, K. 2011. Afri-Nut is up and running! [Online]. The Practitioner Hub. http://businessinnovationfacility.org/profiles/blogs/afri-nut-is-up-and-running. Stiglitz, J.E., 1989. Markets, Market Failures, and Development. The American Economic Review 79 (2), 197-203.

The Economist 2006. Food Politics: Voting with your trolley [Online]. http://www.economist.com/node/8380592. Accessed: 29/06/2012.

Tobin, R.J., Knausenberger, W.I., 1998. Dilemmas of Development: Burley tobacco, the environment and economic growth in Malawi. Journal of Southern African Studies 24 (2), 405-424.

Tsutomu, T., 2009. Disparities and Diversities Among Female-Headed Households in Rural Malawi after 20 Years of Economic Liberalization. Singapore Journal of Tropical Geography 30 (3), 358-372. 
TWIN Trading 2012. Afri-Nut Ltd: a landmark groundnut processing plant for Malawi [Online]. London: http://www.twin.org.uk/projects/afri-nut-ltd-landmarkgroundnut-processing-plant-malawi. Accessed: 31/01/2012.

United Nations, 2011. Human development: statistical annex.

Utting, K., 2008. Assessing the Impact of Fair Trade Coffee: Towards an Integrative Framework. Journal of Business Ethics, 1-23.

Walton, J., 2002. National Smallholder Farmers' Association of Malawi.

ACDI/VOCA, Washington D.C.

Weru, J. 2012. Nyeri factory to sell tea directly to UK's Marks and Spencer [Online]. http://in2eastafrica.net/nyeri-factory-to-sell-tea-directly-to-uk\%E2\%80\%99s-marksand-spencer/. Accessed: 22/02/2012.

Whatmore, S., 1997. Dissecting the autonomous self: hybrid cartographies for a relational ethics. Environment and Planning D: Society and Space 15 (1), 37-53. Yara Prize 2012. The Yara Prize [Online].

http://www.yara.com/sustainability/how_we_engage/africa_engagement/yara_prize/in dex.aspx?WT.mc_id=yara_prize_2012. Accessed: 05/12/2012. 